\title{
OSU Reactor Sharing Program FY 1995 Annual Report
}

Prepared for:

U. S. Department of Energy

By:

Jack F. Higginbotham

Principal Investigator

Radiation Center

Oregon State University

100 Radiation Center

MASTER Corvallis, OR 97331-5903 


\section{DISCLAMIER}

Portions of this document may be illegible in electronic image produets. Images are produced from the best available original document. 


\section{SUMMARY}

This is the annual report of the activities supported under the Oregon State University Reactor Sharing Program, award number DE-FG06-NE38137. The beginning date for the award was September 30, 1995 and the end date was September 29, 1996.

Work conducted under this award is internally administered at the Radiation Center through a project tasking system. This allows for excellent quality control for the work which is performed from the point of initial contact, through the reactor application, project report generation and financial accounting. For the current fiscal year, FY95, the total cost of the reactor sharing program, including Radiation Center contributions, was $\$ 66,323.20$ of which $\$ 40,000.00$ was supplied by the DOE Reactor Sharing Program. The details of individual project costs is given in Table 1.

The work performed for the individual projects are described in the brief work descriptions given in Table 2.

\section{DISCLAIMER}

This report was prepared as an account of work sponsored by an agency of the United States Government. Neither the United States Gnvernment nor any agency thereof, nor any of their emplcyees, makes any warranty, express or implied, or assumes any legal liability or responsibility for the accuracy, completeness, or usefulness of any information, apparatus, product, or process disciosed, or represents that its use would not infringe privately owned rights. Reference herein to any specific commercial product, process, or service by trade name, trademark, manufacturer, or otherwise does not necessarily constitute or imply its endorsement, recommendation, or favoring by the United States Government or any agency thereof. The views and opinions of authors expressed herein do not necessarily state or reflect those of the United States Government or any agency thereof. 
Table 1. 1995-1996 OSTR Reactor Sharing Project Funding DOE Agreement No.: DE-FG06-95NE38137

INSTITUTION
PROJ Univ Oregon/MoBimey
1130 Un
1131 Franklin \& MarshallMiebe
1132 Univ Colorado/Stern
1133 SUNY/Roden-Tice
1134 Univ Colorado/Nerplanck
1135 Trinity Univ/Smith
1136 College of the Siskiyous/Hirt
1137 Clemson UnivMarner
1138 Idaho State/Hughes
1139 N Carolina State/Fodor
1140 Texas Tech/Johnson
1141 Univ Florida/Mueller
1142 George Washington Univ/Tollo
1143 Colorado College/Noblett
1144 Univ Washington/Bergantz
1145 City College of New York/Steiner
1146 McNary High School/Epperson
1147 Univ Puerto Rico/Joyce
1148 UCLADavidson
1149 California StateMNeigand
1150 Univ Puerto Rico/Joyce
1151 UCLACastellana
1152 Univ Colorado/Farmer
1153 Rice Univ/Leeman
1154 Johns Hopkins Univ/Marsh
1155 E New Mexico Univ/Constantopo
1156 Union College/Garver
1157 California State/Kato
1158 Texas Tech/Bames
1159 Univ Oregon/McBirney
1160 Univ Oregon/Goles
1161 Univ Oregon/Goles
1162 Univ New Orleans/Pavlis
1163 San Jose State/DeBari
1164 Corvallis HS/Pittinger
1165 Univ Utah/Adams
1166 Univ Oregon/Reed
1167 Univ Arizona/DeCelles
1168 SUNY/Carl
1169 Williams College/Skinner
1170 Univ Idaho/Wood
TOTALS

\begin{tabular}{rrr}
\multicolumn{1}{c}{ DOE RUS } & \multicolumn{1}{c}{ RAD CTR } & \multicolumn{1}{l}{ TOTAL } \\
CONTRIBUTION & CONTRIBUTION & \multicolumn{1}{l}{ COST } \\
$1,000.00$ & 654.00 & $1,654.00$ \\
$1,000.00$ & 654.00 & $1,654.00$ \\
$1,000.00$ & 654.00 & $1,654.00$ \\
330.00 & 0.00 & 330.00 \\
$1,000.00$ & 654.00 & $1,654.00$ \\
$1,000.00$ & 654.00 & $1,654.00$ \\
$1,000.00$ & 654.00 & $1,654.00$ \\
$1,000.00$ & 654.00 & $1,654.00$ \\
660.00 & 0.00 & 660.00 \\
$1,000.00$ & 654.00 & $1,654.00$ \\
$1,000.00$ & 654.00 & $1,654.00$ \\
$1,000.00$ & 654.00 & $1,654.00$ \\
$1,000.00$ & 654.00 & $1,654.00$ \\
$2,000.00$ & $1,308.00$ & $3,308.00$ \\
CANCEL & & \\
$1,000.00$ & 654.00 & $1,654.00$ \\
$1,000.00$ & 654.00 & $1,654.00$ \\
$1,000.00$ & 654.00 & $1,654.00$ \\
$1,000.00$ & 654.00 & $1,654.00$ \\
$1,000.00$ & 654.00 & $1,654.00$ \\
$1,000.00$ & 654.00 & $1,654.00$ \\
$1,000.00$ & 654.00 & $1,654.00$ \\
$1,000.00$ & 654.00 & $1,654.00$ \\
$1,000.00$ & 654.00 & $1,654.00$ \\
$1,000.00$ & 654.00 & $1,654.00$ \\
$1,000.00$ & 654.00 & $1,654.00$ \\
2220.00 & 0.00 & 220.00 \\
$1,000.00$ & 654.00 & $1,654.00$ \\
$1,000.00$ & 654.00 & $1,654.00$ \\
$1,000.00$ & 654.00 & $1,654.00$ \\
$2,000.00$ & $1,308.00$ & $3,308.00$ \\
$2,000.00$ & $1,308.00$ & $3,308.00$ \\
182.80 & $1,471.20$ & $1,654.00$ \\
$2,000.00$ & $1,308.00$ & $3,308.00$ \\
6607.20 & 0.00 & 607.20 \\
CANCEL & & \\
$1,000.00$ & 654.00 & $1,654.00$ \\
$1,000.00$ & 654.00 & $1,654.00$ \\
$1,000.00$ & 654.00 & $1,654.00$ \\
$1,000.00$ & 654.00 & $1,654.00$ \\
$1,000.00$ & 654.00 & $1,654.00$ \\
$40,000.00$ & $26,323.20$ & $66,323.20$
\end{tabular}


Table 2. OSTR Reactor Sharing Project Descriptions, 1995-1996

Project Description

1130 Determination of trace elements to evaluate the behavior of components during crystallization and differentiation of magmas at shallow depths of the earth's crust and mantle.

1131 Investigations of the bimodal (granite-gabbro) complex where basaltic magmas have been emplaced into an active silicic magma chamber. Research is focused on the interactions between these two magmas at the bottom of the magma chamber and in composite dikes.

1132 Determination of spatial distribution of obsidian artifacts from different archaeological sites in Patagonia resulting from cultural exchange among pre-historic people by the use of trace element INAA.

1133 Evaluation of uplift and thermal histories in the Olympic Mts., WA; Adirondack Mts., NY; Trinidad; Hartford Basin, CT; and the Appalachian Basin.

1134 Identification of the processes responsible for the generation of zoned magma bodies and determination of how silicic magmas are formed, using the Organ Needle pluton as an example.

1135 Investigation of the origin and evolution of magmas emplaced in the Llano uplift of central Texas and the Cyprus ophiolite.

1136 Determination of the internal zoning in the Paradise pluton, Mt. Whitney, and characterization of several associated mafic rocks thought to be possible end members of the suite.

1137 Investigation to relate mineral chemistry to dike chemistry as a function of position in a diabase dike.

1138 Use of INAA to support a large variety of research projects involving the geochemistry of rocks in Idaho and surrounding regions. This includes support for two graduate classes Geology 615 and 625.

1139 Use of trace element abundances in clinopyroxene components of xenoliths to interpret the roles that tholeitic and alkalic magamatism of Hawaiian shield volcanoes played in producing cumulates of dunite, wehrlite and clinopyroxene found as xenoliths in alkalic basalts of volcanoes such as Mauna Kea.

1140 Determination of the origin and source of magnetite ores found throughout one of the trondjemitic intrusions in the composite Cornucopia stock in the Blue Mountains, NE Oregon. 
Table 2. OSTR Reactor Sharing Project Descriptions, 1995-1996 (Continued)

Project Description

1141 Evaluation of whether the $\mathrm{Sr}$ and $\mathrm{Nd}$ isotopic ratios of weathered Himalayan upper crust has changed over the last $15 \mathrm{Ma}$ and, if so, whether it could account for the changes in $\mathrm{Sr}$ and $\mathrm{Nd}$ isotopes in seawater

1142 Analyis of late proterozoic, rift-related granitoids of the central and southern Blue Ridge Province of VA and SC to (1) distinguish different granitoid units (2) formulate petrologic models for the evolution of each pluton, and (3) serve as a basis for the selection of samples for $\mathrm{U}-\mathrm{Pb}$ analysis of zircons.

Geochemical \& petrological analysis of rocks from 1) the Tobacco Root range to find a petrolith for these rocks, and 2) from the Southern Oregon Cascades to examine their tectonic origins.

$1144 \quad$ Canceled

1145 Rare earth element investigation of the Ravenswood Granodiorite exposed in the New York City tunnel project in order to provide adequate compositional control in tracing the boundaries of this, the Fordham Gneiss, and the Hartland Formation.

1146 Determination of the source of sediment brought into the Willamette Valley near Salem from ancient floods. The sediment for analysis includes two layers of silt with a layer of Malpasse clay in between.

1147 Study of the potholith origin and metamorphic history of the metamorphic archean rocks from the Tobacco Root Mountains, Southwestern Montana, through whole rock geochemical analysis.

1148 Evaluation of changes in geochemistry across the Kamchatka Arc to constrain differentiation processes at individual volcanoes and to determine whether the mantle source differs due to variations in the slab derived component or variations in the degree of melting.

1149 Evaluation of the origin of Miocene volcanic rocks from San Clemente and Santa Cruz Islands, CA to document the origin of these calc-alkaline volcanics in an extensional environment.

1150 Detailed geochemical analysis of the Bermeja Complex to establish the relationships between types of alterations and mineralogical and chemical distributions in the Jurassic-Early Cretaceous oceanic crust.

1151 Comparison of the trace element behavior between Avachinskiy and Koryokskiy volcanoes to identify possible sources of magmatic modification. 
Table 2. OSTR Reactor Sharing Project Descriptions, 1995-1996 (Continued)

Project Description

1152

Evaluation of the intrusive rocks in paleoproterozoic collisional orogens as a key to tectonic settling and orogenic development and implications from the Labrador-Greenland connection.

1153

Petrogic study of eastern Snake River Plain basalts to determine the origin of hot-spot related magmatism related to passage of North America over the Yellowstone plume.

1154 Evaluation of rhyolite magma produced beneath Rapa Nui in order to determine what differentiation processes generated the material, and to establish under what heat flow conditions, in what tectonic settings and over what time periods these magmas can be generated from basaltic magmas.

1155 Characterization of the Bonito Lake stock in the Sierra Blanca Igneous Complex to provide a better understanding of the Lincoln County Porphyry Belt.

1156 Determinations of the cooling history of rocks caused by mountain building events.

1157 Analysis of coarse crystalline blueschists from the coast range of south central Chile to provide information on their metamorphism and their relation to other blueschists and greenschists in the region.

1158 Investigation of the origin of monzogranites and related intrusions emplaced during extensional deformation of the Ruby Mountain (NV) core complex during Tertiary time.

1159 Determinatopm of the abundance of Sc and transition metal in ilmenite and magnetite mineral seperates. The evaluation of artitioning coefficients of these elements between mafic silicate melts and iron oxide phases are fundamental in the interpretation of magma genesis and crystal fractionation.

1160 Determination of contents of $\mathrm{Na}, \mathrm{Ca}, \mathrm{Zn}, \mathrm{Sr}$, and $\mathrm{Ba}$ in bones as a guide to human palaeodiet.

1161 Characterization of komatiites from Australia for rare earth element and platinum group element abundances to evaluate their economic mineral resource potential.

1162 Determination of the structural and kinematic geochemical evolution of a zoned granitic pluton and its genetic relationship to apparent granitic pods in deformed country rock. 
Table 2. OSTR Reactor Sharing Project Descriptions, 1995-1996 (Continued)

Project Description

1163 Determination of the geochemistry of the Cardinal Peak pluton to track the petrologic and structural history of the magma chamber with a view to shedding some light on crustal processes worldwide.

1164 Characterization of the geochemistry of calcite and malachite veins in a schist collected in Montana in contrast to the host rock to evaluate the supergene copper mineralization on joint surfaces.

1165 Cancelled

1166 Investigation of compositional heterogeneity within single potsherd to aid in planning further research to determine if there are spatial or chronological groupings of ceramics that can be found via INAA studies.

1167 Geochemical provenance studies of Jurassic paleosols from the Morrison Fm. in Utah to assess paleosol horizonation in response to climatic variability

1168 A comparison of amphibolite layers inside and outside the Hyde School Gneiss to determine if they are geochemically similar and to assess if they are ductilly deformed, realigned dikes.

1169 Determination of the age of New World flint artifacts and fossile teeth from European Paleolithic sites using electron spin resonance to measure accumulated radiation damage.

1170 Determination of the origin, tectonic setting and nature of a series of picritic basalt flows in Eastern Oregon which contain anomalous concentrations of platinum group elements. 